\begin{abstract}
У статті представлено результати експериментальних досліджень гідродинаміки, теплообміну фільтраційного сушіння зерна пшенищі, результати експериментальних досліджень представлені $y$ вигляді безрозмірних комплексів. Отримані розрахункові залежності для визначення коефічієнтів внутрішньої Әифузї залежно від температури теплового агенту та початкового вологовмісту зерна. Визначено рачіональні режими сушіння для насінневого та продовольчого зерна

Ключові слова: зерно пиениці, вологовміст, гіӘродинаміка, теплообмін, дифузія, кінетика сушіння

В статье представлены результаты экспериментальных исследований гидродинамики, теплообмена фильтрационной сушки зерна пшеницы, результаты экспериментальных исследований представлены в виде безразмерных комплексов. Полученные расчетные зависимости для определения коэффициентов внутренней Әиффузии в зависимости от температуры теплового агента и начального влагосодержания зерна. Определены рациональные режимы суики для семенного и продовольственного зерна

Ключевые слова: зерно пшеницы, влагосодержание, гидродинамика, теплообмен, диффузия, кинетика сушки
\end{abstract}

$$
\text { 口- }
$$

\begin{tabular}{c} 
УДК 66.045 \\
DOI: $10.15587 / 1729-4061.2014 .27975$ \\
\hline
\end{tabular}

\section{BASIC \\ REGULARITIES OF THE FILTRATION DRYING OF WHEAT GRAIN}

\author{
I. Matkivska \\ Postgraduate* \\ E-mail: iramatkivska@ukr.net \\ V. A t a m a n y u k \\ Doctor of Technical Sciences, Professor* \\ E-mail: Atamanyuk@ukr.net \\ D. S y m a k \\ Ph.D* \\ E-mail: dsymak3@gmail.com \\ *Department of Chemical Engineering \\ National University "Lviv Polytechnic" \\ S. Bandera str., 12, Lviv, Ukraine, 79013
}

\section{Introduction}

Wheat is one of the most important consumed and widely spread food crops in the world. In recent years, the area of winter wheat in Ukraine has accounted for more than $50 \%$ of all cereals [1]. In addition, in Western Europe countries, the contribution of new varieties into the winter wheat yield level gained in recent years, is $60 \%$ [2]. Therefore, as the object to be investigated, we have chosen the grain of winter wheat variety "Zolotokolosa" which is put on the 2005 Register of Promising Plant Varieties of Ukraine. An average yield of "Zolotokolosa", according to its originator (Institute of Plant Physiology and Generics, NAS of Ukraine), over the trial period (2000-2004), equaled $86,1 \mathrm{dt} / \mathrm{ha}$.

It is well-known that newly gathered grain easily gets out of order; therefore the increase in grain production requires constant improvement of treatment after gathering, where drying stage is the final operation. This stage consumes $70 \%$ of energy of the whole technology. Thus, the development of new methods of wheat grain drying and new drying technique is an urgent problem.

\section{Problem statement}

At the present stage of grain drying in Ukraine and in the world, there is a need to intensify the grain drying process, to create and develope highly-efficient and environmentally-friendly technologies and equipment to be used for grain desiccation. It is known that $8-10 \%$ of all energy available in the world are spent for drying processes [3]. Selecting a method, an optimal mode and design of a grain dryer depends on the material properties, and has to preserve the qualities and properties of wheat grain, with energy resource consumption being minimized [4]. Therefore, offered is the filtration drying method that is one of the highly-intensive, low-temperature and environmentally-safe methods [5].

\section{Literature Review}

As is known, the open air sun (natural) drying can be used to dry small batches of grain. The main advantage of this method is its cheapness, but it does not ensure the maximum possible removal of moisture, and also depends on weather. Artificial drying in dryers is the basic and most effective drying method that prevents the growth of microorganisms, and slows the enzymatic changes, thus significantly increasing the shelf life [6]. The column-type dryers and drum dryers are those ones having a wide use in industry. However, it should be noted that these installations have a number of disadvantages.

The column-type dryers are characterized by a nonuniform distribution of heating medium, a slow movement of grain near the shaft's side walls, and its retention on the duct's upper edges, thus resulting in a non-uniform heating and drying of grain in different parts of the column, as well as the high cost of the apparatus.

The drum dryers, in turn, are characterized by partially damaged grains, low moisture removal in a single pass 
through the dryer, low productivity, cumbersome design, increased consumption of thermal energy.

In recent years, widely spread have been the fluidizedbed dryers which are characterized by rapid equalization of grain temperature, and intensive heat-and-mass exchange. However, the disadvantages of such dryers are high hydraulic resistance, removal and damage of grains [7]. The infrared radiation dryers [8] are also used in practice. Such a method allows for moisture removal at low temperatures $\left(40-60{ }^{\circ} \mathrm{C}\right)$. The advantages of this method can also be the shortness and high effectiveness of the process. However, these dryers have low efficiency, high-fire risk, and significant energy consumption per $1 \mathrm{~kg}$ of evaporated moisture.

The authors of the paper [9] suggest using a blocktype grain dryer which allows to save up to $30 \%$ of power compared to the column-type grain dryers, and the paper [10] deals with the ways to intensify the process in the drumtype grain dryer.

At the same time, it should be noted that the problem of major disadvantages in using these apparatus is not solved in the above mentioned papers, therefore, the development of a new highly efficient equipment is an urgent task.

\section{The purpose of the paper}

The purpose of the paper is to theoretically analyze and experimentally investigate the appropriateness of using the filtration drying of wheat grain, and to determine the optimum regimes, including the impact of the averaged sizes of wheat grains on the pressure loss in the stationary layer. Also, to check the hydrodynamicsspecific and heat-exchange-specific results obtained using experimental equipment against those obtained using a filtration drying pilot installation, and to determine their adequacy.

Investigation tasks:

1. To experimentally investigate how the pressure losse es in the stationary layer of wheat grain depend on the filtration rate of thermal agent, and on the averaged sizes of grains.

2. To carry out experimental investigations into the heat exchange using a filtration drying pilot installation, and to compare the results obtained with those theoretically calculated.

3. Based on the kinetics of filtration drying, to determine how the internal diffusion coefficient for the moisture from wheat grain depend on the initial moisture content and temperature of the thermal agent.

4. To experimentally investigate how the drying temperature influence the germinative capacity of wheat grain, and to determine the optimum regimes.

\section{Investigation objects and procedure}

The winter wheat variety "Zolotokolosa" grain has been chosen to carry out experimental investigations. The basic technical characteristics we have determined for the individual grains and for the stationary layer of test material are given in [12]. Experimental investigations into hydrodynamics, kinetics and heat-exchange during the filtration drying of wheat grain have been conducted using a pilot installation and through the techniques tried by many authors, as given in [5].

\section{Results and Discussion}

In our previous papers we suggested the design dependences to determine the hydraulic friction factor $\lambda$, and established its dependence on the Reynolds number [11]:

$$
\lambda=\frac{145}{\operatorname{Re}_{\mathrm{e}}}+1.9 .
$$

The experimental data has been generalized based on the inner problem of hydrodynamics (the characteristic size has been taken to be an equivalent diameter of the channels which are formed by the layer particles, and through which a heating medium is filtered) in dimensionless groups, and as a result the following design dependence has been proposed [11]:

$$
\mathrm{Eu}=3.8 \cdot \frac{\mathrm{H}_{\mathrm{e}}}{\mathrm{d}_{\mathrm{e}}} \cdot \operatorname{Re}_{\mathrm{e}}^{-0.2} .
$$

It should be noted that the heating medium, when being filtered through the stationary layer of disperse material, does not only move in the channels between the grains, but also flows around every grain separately (exterior problem of hydrodynamics). That is, the real process is a mixed problem of hydrodynamics.

Therefore, we have carried out additional experimental investigations to determine the effect of the grains' averaged diameter on the hydrodynamics of the filtration drying process, and obtained a design dependence for the exterior problem of hydrodynamics:

$$
\mathrm{Eu}=55 \cdot \frac{\mathrm{H}}{\mathrm{d}_{\text {ч }}} \cdot \operatorname{Re}^{-0.2} .
$$

In order to obtain the design dependence, which would take into account the material grading and the effect of the equivalent diameter of the channels through which the gas flow is filtered, and the size of the particles themselves (a mixed problem of hydrodynamics), it should be appropriate for the design dependence (2) to include a geometrical simplex $\Gamma$ which takes into account the relation between the container diameter and the particle diameter. It is known that the geometrical simplex for disperse materials is given by [5]:

$$
\Gamma=\left(\frac{d_{\mathrm{u}}}{D_{a}}\right)^{0.67} .
$$

Then, the criterion equation (2) becomes:

$$
\mathrm{Eu}=35 \cdot \frac{\mathrm{H}_{\mathrm{e}}}{\mathrm{d}_{\mathrm{e}}} \cdot \operatorname{Re}_{\mathrm{e}}^{-0.2} \cdot\left(\frac{\mathrm{d}_{\mathrm{u}}}{\mathrm{D}_{\mathrm{a}}}\right)^{0.67}
$$

The experimental data representations in the form of dimensionless numbers are easy-to-use in practice and enable, in the phase of drying equipment design, to predict the pressure loss in the stationary layer of wheat grain during the filtration drying, and, correspondingly, determine the energy cost and the economic feasibility of the process. 
The design dependences (1) and (5) obtained for an experimental set-up have been used by us to predict the pressure losses on a pilot installation the schematic of which is given in [12]. The correlation dependence between the calculated values of pressure loss based on (1) and (5), and the experimental data obtained on the pilot installation, is given in Fig. 1, 2.

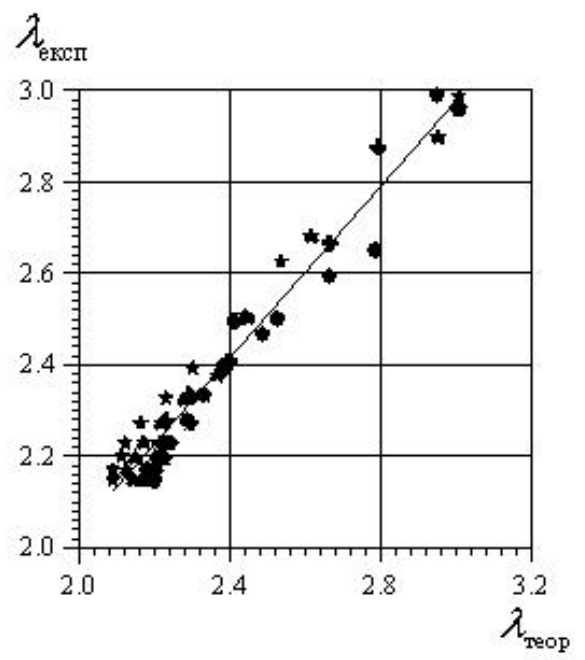

Fig. 1. Correlation dependence between the theoretically calculated values of hydraulic friction factors and the experimental values

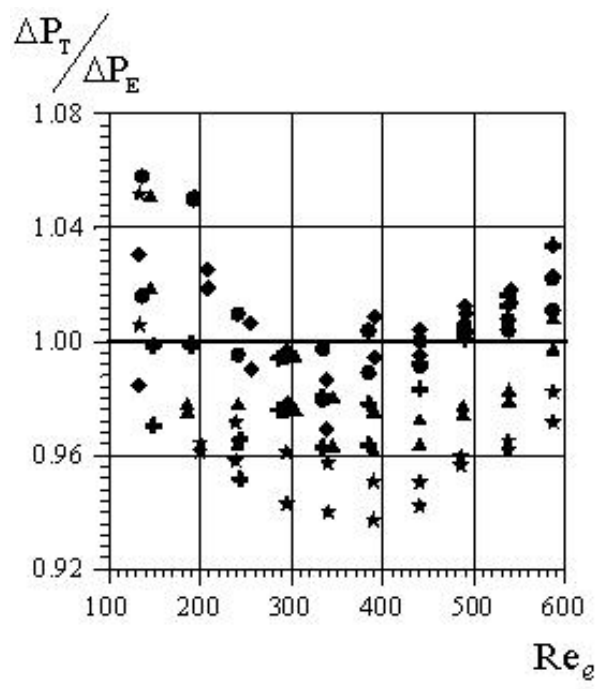

Fig. 2. Correlation dependence between the relation $\Delta \mathrm{P}_{\mathrm{T}} / \Delta \mathrm{P}_{\mathrm{E}}$ and the Reynolds number

Analysis of Fig. 1, 2 has shown that the greatest possible error in the use of theoretical dependence data does not exceed $9.6 \%$. Thus, the proposed design dependences (1) and (5) may be used for practical computation of drying equipment.

Determining the optimal parameters of filtration drying process is ensured by the investigation into heat exchange specificities and their generalization in the form of dimensionless numbers that would enable to compute the heat rejection factors, with the filtration modes and physical parameters of the heating medium being known. The results of experimental investigations into the external heat exchange between the heating medium and the wheat grain we obtained earlier, are given in [13]. The generalizations are given in the form of criterion dependences:

- for the wet wheat grain:

$$
\mathrm{Nu}=0.072 \cdot \operatorname{Re}_{\mathrm{e}}^{0.5} \cdot \operatorname{Pr}^{0.33},
$$

- for the dry wheat grain:

$$
\mathrm{Nu}=0.077 \cdot \operatorname{Re}_{\mathrm{e}}^{0.75} \cdot \operatorname{Pr}^{0.33} \text {. }
$$

As in the case of hydrodynamics, we have examined the theoretical results using a pilot installation. The examination has shown that the maximum relative error between the experimental values and the values computed against dependencies (6), (7), does not exceed $\pm 11.9 \%$.

The intensity of wheat grain drying is defined by the coefficient of internal moisture diffusion. Therefore, based on the experimental investigations into the filtration drying kinetics, as given in [14], we have determined the internal diffusion coefficient $D_{w}$, following the solution to the differential diffusion equation which is generally given by [15]:

$$
\frac{\partial w^{c}}{\partial \tau}=D_{w} \cdot\left(\frac{\partial^{2} w^{c}}{\partial r^{2}}+\frac{1}{r} \cdot \frac{\partial w^{c}}{\partial r}+\frac{\partial^{2} w^{c}}{\partial z^{2}}\right),
$$

with the first-order boundary conditions being used for a cylinder of finite size. The internal diffusion coefficient values for the wheat variety "Zolotokolosa" are given in Table 1.

Generalizing the experimental results given in Table 1 has made it possible to obtain the following approximation dependency:

$$
\mathrm{D}_{\mathrm{w}}=\mathrm{D}_{\mathrm{w}}^{293}+0,3 \cdot 10^{-13} \cdot(\mathrm{T}-293)^{2} \cdot\left(\mathrm{w}^{\mathrm{c}}\right)^{-1.8} .
$$

The design dependency given to determine the internal diffusion coefficient is true for the temperature range $313 \leq t \geq 353 \mathrm{~K}$ and for the range of wheat initial moisture content values $0.219 \leq \mathrm{w}^{\mathrm{c}} \geq 0.304 \mathrm{~kg} \mathrm{H}_{2} \mathrm{O} / \mathrm{kg}$ dry weight.

The resulting design dependency may be used to predict the duration of the wheat grain filtration drying. Comparisons of the computed values of drying duration, based on the dependence (9), with the experimental data obtained on the pilot installation, completely agree within the specified limits of heating medium temperatures and initial moistures.

Table 1

Values of internal diffusion coefficients $D_{w}$ at different temperatures of the heating medium and the initial moisture content of grain

\begin{tabular}{|c|c|c|}
\hline \multirow{2}{*}{$\mathrm{K}, \mathrm{K}$} & $\mathrm{w}^{\mathrm{c}}, \mathrm{kg} \mathrm{H} \mathrm{H}_{2} \mathrm{O} / \mathrm{kg}$ dry weight & $\mathrm{D}_{\mathrm{w}} \cdot 10^{10}, \mathrm{~m}^{2} / \mathrm{s}$ \\
\hline 293 & 0.239 & 0.4 \\
\hline 313 & 0.239 & 2.1 \\
\hline 323 & 0.239 & 3.76 \\
\hline \multirow{3}{*}{333} & 0.219 & 8 \\
\cline { 2 - 3 } & 0.239 & 7.41 \\
\cline { 2 - 3 } & 0.258 & 6.1 \\
\cline { 2 - 3 } & 0.269 & 5.22 \\
\hline 353 & 0.304 & 5.07 \\
\hline
\end{tabular}


When choosing a filtration drying mode, account should be primarily taken of the grain intended use. The basic criterion for the quality of seed grain is its germination, i. e. the seed ability to yield, under optimum conditions, normally-developed sprouts to be determined by the percentage ratio of sprouted seeds to their total quantity [18].

The wheat grain drying duration is essentially influenced by the heating medium temperature [14], that is, with the heating medium temperature being raised the process is intensified, and with the heating medium temperature being increased from $40{ }^{\circ} \mathrm{C}$ to $80{ }^{\circ} \mathrm{C}$ the drying duration is reduced by 6 times, this is due to an increase in the drying potential of heating medium, and to an increase in the coefficients of internal moisture diffusion from the wheat grain.

However, any temperature rise adversely affects the quality of wheat grain. Therefore, investigated has been the effect of heating medium temperature on the wheat grain germinating ability. After the wheat grain has been dried in the pilot installation at different temperatures, 100 grains have been randomly taken from the entire batch for each subsequent experiment, and then tested for their germinating ability. To do this, the grains taken have been uniformly arranged on a damped filter paper placed into the Petri dishes to be further installed in a well-ventilated room in which the temperature has been maintained at $20 \pm 0.5{ }^{\circ} \mathrm{C}$ for 7 days. The results of investigations into the temperature effect on the wheat grain germinating ability are given in Fig. 3.

Analysis of the results obtained has shown that the heating medium temperature has a significant impact on the quality indicators of wheat grain. A high germinating ability of grain has been observed during the filtration drying by the heating medium with a temperature of $40{ }^{\circ} \mathrm{C}$ and $50{ }^{\circ} \mathrm{C}$, to equal $99 \%-98 \%$, respectively, while at a temperature of $60{ }^{\circ} \mathrm{C}$ the germinating ability has fallen to $90 \%$. With a heating medium temperature of $80{ }^{\circ} \mathrm{C}$, the grain germinating ability has been less than $30 \%$, therefore, the rational mode of wheat seed filtration drying can be considered a temperature of $50 \pm 2^{\circ} \mathrm{C}$. In addition, the chemical composition of wheat grain, as determined by a factory laboratory, at a drying temperature of $60{ }^{\circ} \mathrm{C}$, has been in conformity with the normal condition. Therefore, a heating medium temperature of $60 \pm 2{ }^{\circ} \mathrm{C}$ may be recommended for the food wheat grain, and this will make it possible to reduce the time needed for its drying, and to improve the drying system productivity.

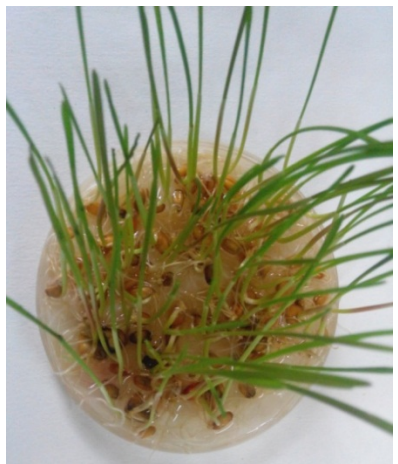

$a$

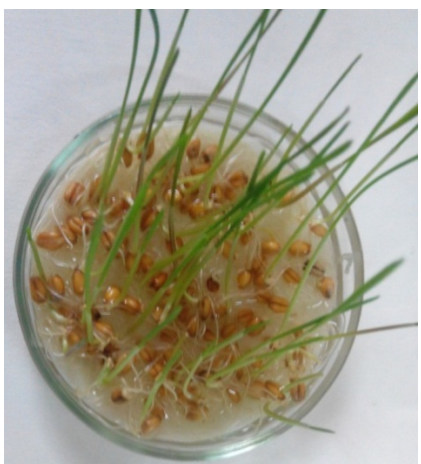

$b$
Fig. 3. Wheat grain germinating ability depending on the effect of heating medium temperature: $a-50{ }^{\circ} \mathrm{C} ; b-60{ }^{\circ} \mathrm{C}$

\section{Conclusion}

The results obtained make it possible to predict, with sufficient accuracy, the hydraulic resistance of the stationary layer of wheat grain. Comparison of the calculated values of heat-exchange coefficients for the dependences (6), (7) with the experimental results obtained using a pilot installation of filtration drying has proved their adequacy and appropriateness of use in designing new equipment (the maximum relative error between the experimental and calculated values did not exceed $\pm 11,9 \%$ ). Based on the kinetics of filtration drying, experimentally determined is the internal diffusion coefficient, and determined is its dependence on the initial moisture content and temperature (dependence (9)), which allows to predict the filtration drying duration for wheat grain. Experimentally determined are the optimum parameters for the thermal agent to ensure the high quality of seed and food grains. The results obtained allow to assert the appropriateness of using the filtration method to dry the wheat variety "Zolotokolosa" grain.

\section{References}

1. Burlaka, N. I. Ukraine as a world exporter of grains [Text] / N. I. Burlaka // Collected Works VNAU. - 2012. - № 3(69). - P. 36-41.

2. Voziyan, V. Technological properties of grain of winter wheat varieties of different eco-heohafichnoho origin [Text] / V. V. Voziyan, V. V. Lubich, O. G. Suhomud // Collected Works VNAU. - 2013. - № 1(71). - P. 121-125.

3. Mujumdar, A. S. Progress in drying technologies [Text] / A. S. Mujumdar, T. Kudre. - 2001. - Vol. 7. - 459 p.

4. Snyezhkin, Y. F. Heat pump grain dryer for seed grain [Text] : monograph / Y. F. Snyezhkin, V. M. Pazyuk, J. O. Petrova, D. M Chalayev. - Kyiv: LLC «Printing-Service», 2012. - 154 p.

5. Atamanyuk, V. M. Scientific basis of filtration drying of dispersed materials [Text] : monograph / V. M. Atamanyuk, Ja. M. Humnytskyy. - Lviv: Publishing House of Lviv Polytechnic National University, 2013. - 276 p.

6. Jayas, D. S. Preserving quality during grain drying and techniques for measuring grain quality [Text] / D. S. Jayas, P. K. Ghosh // 9 th International Working Conference on Stored Product Protection. - 2006. - P. 969-980.

7. Fesenko, A. V. Improving the efficiency of drying process of crops [Text] : dis. kan. tehn. sciences: 05.05.11/ Andrey Fesenko. Lugansk, 2006. - $170 \mathrm{p}$.

8. Pronichev, S. A. Pulsed infrared drying of seed grain [Text] : author. candidate ... candidate. tehn sciences. / S. A. Pronichev. - M., 2007. $-21 \mathrm{p}$.

9. Burdo, A. G. Kinetics of drying wheat in devices based on termosyfoniv [Text] / A. H. Burdo, I. V. Bezbakh, V. I. Donkhlov // Collected Works ONAFT. - 2009. - Vol. 36, Issue 1. - P. 297-302. 
10. Vinokurov, K. V. Road intensification of the process of grain drying in the dryer drum [Text] / K. V. Vinokurov, S. N. Nikonorov, V. M. Sedelkina // Materials II Intern. scientific-practical. conf. Modern energy-saving heating technology SETT-2005 (Moscow, 11-14 October. 2005). - M., 2005. - T. 1. - P. 233-236.

11. Atamanyuk, V. M. Features Hydrodynamic filtration drying wheat [Text] / V. M. Atamanyuk, I. Ja. Matkivska, M. I. Mosiuk // Collected Works ONAFT. -2013. - Vol. 2, Issue 43. - P. 10-16

12. Deklar. Pat. a utility model UA-78 453, IPC 2006.01. Installation of filtration dry bulk materials [Text] / Atamanyuk V. M., Huzova I. A., Matkivska I. J., Mazyar G. O. - u 2012 08120; published. 03.25.2013, Bull №6. - 4 p.

13. Atamanyuk, V. M. Heat and Mass Transfer during filtration drying wheat [Text] / I. Ja. Matkivska, D. M. Symak, V. M. Atamanyuk // Chemical Industry of Ukraine. - Kyiv, 2013. - №2. - P. 55-59.

14. Matkivska, I. Ja. Kinetics of drying wheat filtration method [Text] / I. Ja. Matkivska, V. M. Atamanyuk, I. R. Barna // Proceedings of the National Technical University «KPI». - Kharkiv, 2014. - №17. - P. 130-138.

15. Lykov, A. V. Theory of Heat Conduction [Text] / A. V. Lykov. - M.: High School, 1967. - 600 p.

16. DSTU 2240-1993. Crop seeds. Varieties and crop quality. Specifications [Text]. - K.: State Standard of Ukraine, 1993. - 74 p.

\begin{abstract}
На основі варіаційного методу Рітияа та теорії збурень обчислено енергію іонізачії мілких донорів для випадку $L_{1}$ та $\Delta_{1}$ моделі зони провідності монокристалів германію. Порівняння теоретичних розрахунків з експериментальними даними показуе, що водневоподібна модель домішки є наближеною $i$ може бути використана лише для домішки $S b$ в германії. Для домішок, наприклад, Р та As необхідно враховувати хімічний зсув

Ключові слова: теорія збурень, варіачійний метод Ріти, м, монокристали германію, енергія іонізачії, інверcis muny $\left(L_{1}-\Delta_{1}\right)$
\end{abstract}

На основе вариационного метода Ритца и теории возмущений вычислена энергия ионизачии мелких доноров для случая L1 и $\Delta 1$ модели зоны проводимости монокристаллов германия. Сравнение теоретических расчетов с экспериментальными данными показывает, ито водородоподобная модель примеси является приближенной и может быть использована только для примеси $S b$ в германии. Для примесей, например, Р и Аs необходимо учитывать химический сдвиг

Ключевые слова: теория возмущений, вариачионный метод Ритиа, монокристаллы германия, энергия ионизачии, инверсия типа $\left(\mathrm{L}_{1}-\Delta_{1}\right)$
УДК 621.315 .592

DOI: $10.15587 / 1729-4061.2014 .27985$

ВПЛИВ ІНВЕРСІї TИПУ $\left(L_{1}-\Delta_{1}\right)$ АБСОЛюТНОГО MIHIMУMУ НА ЕНЕРГІЮ ІОНІЗАЦІЇ ОСНОВНОГО СТАНУ МІЛКИХ ДОНОРІВ В МОНОКРИСТАЛАХ n-Ge

\section{C.В.Лун ь ов}

Кандидат фізико-математичних наук, доцент Кафредра фрізики і електротехніки Луцький національний технічний університет вул. Львіська 75, м. Луцьк, Україна, 43018 E-mail: luniovser@mail.ru

\section{1. Вступ}

В анізотропному середовищі, на відміну від ізотропного, існує багато явищ, зумовлених анізотропними властивостями кристалів, вивчення яких важливе як 3 теоретичної, так і з експериментальної точок зору. Комплексні дослідження цих явищ є джерелом цінної інформації про енергетичну структуру напівпровідників, механізми розсіяння носіїв заряду та інші важливі дані, які є необхідними для розуміння фізичних процесів, які відбуваються в твердому тілі. Дослідження явищ переносу в анізотропному середовищі важливе ще й тому, що на основі них грунтується робота багатьох напівпровідникових приладів. Одним із таких перспективних анізотропних напівпровідників був і залишається германій, який широко використовується для виготовлення діодів, тріодів, силових випрямлячів, в дозиметричних приборах і приладах, що вимірюють напруженість постійних і змінних магнітних полів [1]. Монокристали германію з мінімальним вмістом дефектів і домішок є перспективним матеріалом для потреб наноелектроніки. Бездислокаційний германій забезпечує вирішення проблем, які виникають у зв'язку з використанням кремнію при створенні нанорозмірних транзисторних структур. Також для опису багатьох кінетичних ефектів як в об'ємних кристалах, так і наноструктурах, необхідно вивчити вплив пружних деформацій на положення локальних 